\title{
KETERAMPILAN MENULIS KALIMAT SEDERHANA BAHASA JERMAN DENGAN MENGGUNAKAN MEDIA GAMBAR SISWA KELAS XI IPA MADRASAH ALIYAH NEGERI 1 MAKASSAR
}

\author{
Andi Meryam ${ }^{1}$ dan Misnawaty Usman ${ }^{2}$ \\ Fakultas Bahasa dan Sastra, Universitas Negeri Makassar \\ Email1': meryam@gmail.com
}

\begin{abstract}
ABSTRAK
Tujuan penelitian ini adalah untuk mengetahui tingkat keterampilan menulis kalimat sederhana bahasa Jerman dengan menggunakan media gambar siswa kelas XI IPA 1 MAN 1 Makassar. Penelitian ini menggunakan metode deskriptif. Populasi dalam penelitian ini adalah siswa kelas XI IPA Madrasah Aliyah Negeri (MAN) 1 Makassar yang berjumlah 74 siswa dari 4 kelas. Sampel penelitian ini adalah siswa kelas XI IPA 1 Madrasah Aliyah Negeri (MAN) 1 Makassar yang berjumlah 25 siswa. Hasil analisis data menunjukkan bahwa keterampilan menulis kalimat sederhana bahasa Jerman dengan menggunakan media gambar siswa kelas XI IPA Madrasah Aliyah Negeri (MAN) 1 Makassar termasuk kategori cukup ( 60,93\%).
\end{abstract}

Kata Kunci: Kemampuan Menulis, Gambar, Media, Kalimat Sederhana

\begin{abstract}
This study aims to determine the skill level of writing simple sentence in German by using picture media by the student of class XI IPA1 MAN 1 Makassar. This research uses descriptive method. The population were the students of class XI IPA Madrasah AliyahNegeri (MAN) 1 Makassar which amounted to 74 students from 4 classes. The sample were the students of class XI IPA1 Madrasah Aliyah Negeri (MAN) 1 Makassar, amounting to 25 students. The results showed that the skill of writing simple sentence of German by using image media the student of class XI IPA Madrasah AliyahNegeri (MAN) 1 Makassar was in enough category $(60,93 \%)$.
\end{abstract}

\section{Keywords: Writing Skill, Picture, Media, Simple Sensence}

\section{PENDAHULUAN}

Penguasaan bahasa asing merupakan salah satu cara yang efektif untuk meningkatkan wawasan umum dan mempersiapkan diri menjadi manusia yang cerdas dalam menghadapi globalisasi.
Salah satu kompetensi berbahasa yang sangat penting untuk dikembangkan adalah keterampilan menulis, karena keterampilan menulis yang dapat memotivasi siswa dalam mengembangkan ide, gagasan, dan pikirannya melalui bentuk tulisan. Menulis merupakan 
salah satu cara yang efektif untuk mengetahui kemampuan siswa dalam berimajinasi secara aktif, inovatif dan kreatif..

Keterampilan menulis adalah suatu bentuk manifestasi keterampilan bahasa setelah kemampuan mendengar, berbicara, membaca. Di bandingkan dengan tiga kemampuan berbahasa yang lain, tanpa kosakata dan tatabahasa mustahil bagi seseorang untuk bisa membuat kalimat dalam bahasa Jerman, karena menulis merupakan proses kreatif yang harus diasah secara terusmenerus.

Media gambar dengan menulis kalimat sederhana ini dilakukan untuk mengembangkan daya kreatif peserta didik dalam kemampuan imajinasi agar dapat memaparkan penjabaran apa yang ia gambarkan dalam bentuk tempelan gambar dan kata-kata yang disisipkan dalam sebuahkertas. media gambar pembelajar tidak merasa monoton ketika sedang diadakan pembelajaran penulisan membuat kalimat sederhana.

Hal tersebut didukung oleh hasil penelitian yang dilakukan oleh Ramadhani (2010) menyimpulkan bahwa keterampilan menulis kalimat sederhana bahasa Jerman melalui media gambar SMA 5 NEGERI MAKASSAR tergolong masih rendah (34,37\%: 43 ). Demikian pula hasil penelitian Misbah (2011) bahwa keterampilan menulis kalimat sederhana bahasa Jerman melalui media gambarkelas XI SMA Negeri 1 Borong Sinjai masih tergolong rendah $(47,33 \%$ : 22$)$.

Berdasarkan latar belakang yang telah dikemukakan di atas, maka rumusan masalah dalam penelitian adalah: "Bagaimana tingkat keterampilan menulis kalimat sederhana dengan menggunakan media gambar siswa kelas XI IPA Madrasah Aliyah Negeri (MAN) 1 Makassar, serta faktor-Faktor apakah yang memengaruhi keterampilan menulis kalimat sederhana bahasa Jerman dengan menggunakan media gambar".

\section{HAKIKAT MENULIS}

Dalman (2014: 37) menyatakan "menulis merupakan proses aktivitas kreatif manusia dalam menyampaikan pikiran atau gagasan, angan-angan, atau perasaan yang menggunakan bahasa tulis sebagai medianya".

Menurut Saddhono dan Slamet (2012: 96) menulis adalah: "kegiatan menggali pikiran dan perasaan mengenai suatu subjek, memilih hal-hal yang akan di tulis, menentukan cara menuliskannya sehingga pembaca dapat memahaminya dengan mudah dan jelas pada dasarnya menulis itu, bukan hanya sekedar melahirkan pikiran atau perasaan saja, melainkan juga merupakan pengungkapan ide, pengetahuan, ilmu, dan pengalaman hidup seseorang dalam bahasa tulis. Oleh karena itu, menulis bukanlah kegiatan yang sederhana dan tidak perlu dipelajari, tetapi justru dikuasai”.

Kast (1999: 23) mengemukakan bahwa menulis adalah keterampilan seseorang dalam mengespresikan gagasan, ide dan pikiran melalui media alat tulis yang berbentuk bahasa tulis ke dalam lambang-lambang kebahasaan sehingga menulis merupakan sarana komunikasi yang sangat penting dalam segala aspek kehidupan.

Saddhono dan Slamet (2012: 95) berpendapat bahwa "keterampilan menulis merupakan keterampilan berbahasa yang sangat penting bagi pelajar, di samping 
keterampilan menyimak, berbicara, dan membaca baik selama mereka mengikuti pendidikan diberbagai jenjang dan jenis sekolah maupun dalam kehidupannya nanti di masyarakat".

Nurgiyantoro (2010: 422) memaparkan bahwa "menulis dibanding tiga kompetensi berbahasa yang lain, kompetensi menulis secara umum boleh dikatakan lebih sulit dikuasai bahkan oleh penutur asli bahasa yang bersangkutan sekalipun”. Berdasarkan uraian di atas disimpulkan bahwa keterampilan menulis adalah kelebihanseseorang dalam berkomunikasi secara tidak langsung yang menggambarkan melalui bahasa tulis.

Tarigan (2008: 24) memaparkan bahwa tujuan menulis adalah "(a) memberitahukan atau mengajar; (b) menyakinkan atau mendesak; (c) menghibur atau menyenangkan; (d) mengutarakan/ mengekspresikan perasaan dan emosi yang berapi-api".

Iskandar Wassid dan Sunendar (2008: 292) menyebutkan bahwa "tujuan kemampuan menulis bagi tingkat pemula yaitu: (a) menyalin satuan bahasa yang sederhana; (b) menulis satuan bahasa yang sederhana; (c) menulis pernyataan- pernyataan yang sederhana; (d) menulis paragraf pendek".

Flower dan Hayes dalam Zainurrahman (2011: 75) menyebutkan bahwa "proses menulis seharusnya dipandang sebagai satu set proses berfikir secara khusus yang dilakukan oleh penulis". Menurut Semi (2007: 46) tahapan atau proses penulisan terbagi atas tiga tahap. Secara garis besarnya dapat diuraikan sebagai berikut: (a) tahap pratulis, yaitu tahap pertama dalam menulis yang sangat menentukan kelanjutan proses menulis; (b) Tahap penulisan merupakan bagian yang paling penting karena pada tahap ini semua persiapan yang dilakukan sebelumnya pada tahap pratulis dituangkan dalam tulisan. Pada tahap ini, penulis harus benar-benar berkonsentrasi pada tulisannya. (c) Tahap pascatulis merupakan tahap penyelesaian akhir tulisan. Berdasarkan uraian di atas dapat disimpulkan bahwa tahap penulisan terdiri atas tiga yaitu pertama tahap pratulis merupakan perencanaan awal sebelum menulis, kedua yaitu tahap penulisan merupakan puncak dari penulisan dan tahap pascatulis merupakan penyelesaian dari tulisan.

\section{FAKTOR YANG MEMENGARUHI KETERAMPILAN MENULIS}

Perdana (2010: 10) mengemukakan bahwa ada beberapa faktor-faktor penunjang untuk menulis antara lain (a) Faktor internal atau faktor dari dalam diri penulis, meliputi: minat, seorang penulis yang memiliki minat yang kuat akan menghasilkan karya tulis yang baik. Motivasi, sebagai usaha yang dapat menimbulkan dorongan kepada individu, intelegensi, kompetensi atau yang lebih erat kaitannya dengan sistem; (b) Faktor eksternal atau faktor dari luar diri penulis, yaitu: prasarana dan sarana yang menunjang berhasilnya sebuah tulisan. Lingkungan sosial penulis, misalnya guru, orang tua dan teman, yang dapat membantu memberi dukungan kepada penulis untuk membuat karya tulis.

Adapun faktor-faktor penghambat dari menulis, menurut Kuncoro (2009: 6-7) faktorfaktor yang menjadi penghambat untuk menulis antara lain (a) Faktor internal yaitu faktor penghambat yang ada dalam diri sendiri 
yaitu: (1) seorang individu yang belum memiliki kebiasaan membaca buku; (2) belum memiliki kemampuan berbahasa yang baik; (3) belum adanya minat dan keinginan untuk menulis. (b) Faktor eksternal yaitu faktor penghambat yang ada di luar pribadi individu yaitu: (1) sulitnya mendapat bahan acuan dan referensi untuk menulis; (2) sulit mencari tema atau topik untuk bahan tulisan; (3) kesulitan dalam penyusunan kalimat baku.

Berdasarkan pendapat di atas, faktorfaktor keterampilan menulis terdiri dari faktor-faktor penunjang untuk menulis antara lain faktor internal meliputi minat, motivasi, kompetensi dan faktor-faktor eksternal yaitu lingkungan sosial. Faktor-faktor penghambat dari menulis yang terdiri dari faktor internal yaitu faktor penghambat yang ada dalam diri sendiri dan faktor eksternal yaitu faktor penghambat yang ada di luar pribadi individu.

\section{HAKIKAT MEDIA GAMBAR}

Menurut Aqib (2013:50) "media pembelajaran adalah segala sesuatu yang dapat digunakan untuk menyalurkan pesan dan merangsang terjadinya proses belajar pada si pembelajar (siswa)." Musfiqon (2012:28) mendefinisikan bahwa "media pembelajaran sebagai alat bantu berupa fisik maupun nonfisik yang sengaja digunakan sebagian perantara antara guru dan siswa dalam memahami materi pembelajaran agar lebih efektif dan efisien".

Berdasarkan pendapat di atas, dapat disimpulkan bahwa media pembelajaran adalah alat yang digunakan untuk menyalurkan pesan dari pengirim ke penerima pesan sehingga terjadi proses pembelajaran yang efektif.
Menurut Sanaky (2009:7) "empat fungsi media pembelajaran yang khususnya pada media visual, yaitu media fungsi atensi, fungsi efektif, fungsi kognitif, dan fungsi kompensatoris". Menurut McKnown dalam Musfiqon (2012:34) mengemukakan ada empat fungsi media pembelajaran, yaitu (1) mengubah titik berat pendidikan formal, yaitu dari pendidikan yang menekankan pada instruksional akademis menjadi pendidikan yang mementingkan kebutuhan kehidupan peserta didik; (2) membangkitkan motivasi belajar pada peserta didik; (3) memberikan kejelasan (clarification); dan (4) memberikan rangsangan (stimulation)".

Berdasarkan pendapat di atas, maka disimpulkan bahwa fungsi media pembelajaran adalah sebagai alat bantu siswa dalam proses pembelajaran, yaitu berupa media dan sarana yang dibuat oleh guru untuk membantu siswa agar lebih tertarik, senang, dan mudah dipahami yang dapat memberikan rangsangan.

Sadiman (2012: 29) mendifinisikan bahwa "gambar adalah media yang paling umum dipakai, yang dapat dimengerti dan dinikmati di mana-mana. Menurut Rohani dalam Musfiqon (2012:16) menyatakan bahwa "media gambar adalah media yang merupakan reproduksi bentuk asli dalam dua dimensi, yang berupa foto atau lukisan".

Berdasarkan pendapat di atas, maka dapat disimpulkan bahwa media gambar adalah media yang umum digunakan yang berupa foto atau lukisan, mudah dipahami dan dimengerti dalam bentuk grafis.

Menurut Nurhadiat (2014:48) ada tiga langkah menggunakan media gambar, yakni (1) Alternatif pertama, pengenalan 
lingkungan, mengamati teknik; (2) Alternatif kedua, siswa berpacu mengeluarkan pendapat tentang perbandingan gambar yang disediakan; (3) Alternatif ketiga, membandingkan berbagai jenis gambar serta uji pemahaman sebagai pembangkit imajinasi.

Menurut Rochmani (2011:18) bahwa langkah-langkah media gambar adalah (1) Kegiatan awal, terdiri dari salam pembuka, dan menjelaskan tujuan pembelajaran; (2) Kegiatan inti, guru menunjukkan gambar kepada siswa dan memberikan contoh pelafalan yang tepat; (3) Penutup, guru menginformasikan kepada siswa tentang kesimpulan pembelajaran".

Berdasarkan pendapat di atas, dapat disimpulkan bahwa langkah-langkah pembelajaran dengan menggunakan media gambar adalahguru menunjukkan gambar kepada siswa dan memberikan contoh pelafalan yang tepat, kedua, siswa berpacu mengeluarkan pendapat tentang perbandingan gambar yang disediakan dan memantapkan pemahaman siswa terhadap pokok materi atau pengajaran.

\section{METODE PENELITIAN}

Penelitian ini menggunakan variabel tunggal yaitu keterampilan menulis kalimat sederhana dengan menggunakan media gambar siswa kelas XI IPA1 MAN 1 Makassar. Penelitian ini adalah penelitian deskriptif yang bertujuan untuk menggambarkan secara objektif tentang keterampilan siswa kelas XI IPA 1 MAN 1 Makassar dalam menulis kalimat sederhana bahasa Jerman dengan menggunakan media gambar.
Keterampilan menulis yang dimaksud dalam penelitian ini adalah menulis kalimat sederhana bahasa Jerman yang terdiri atas subjek, predikat, objekdan kata keterangan. Untuk mengukur variabel dalam penelitian ini, siswa diberikan tes menulis kalimat sederhana bahasa Jerman melalui media gambar. Selanjutnya penilaian yang digunakan dalam penelitian ini oleh Nurgiyantoro (2010:430).

Populasi penelitian ini adalah seluruh kelas XI IPA Madrasah Aliyah Negeri (MAN) 1 Makassar yang terdiridari 4 kelas dengan jumlah 74 siswa. Sampel yang digunakan dalam penelitian ini adalah kelas XI IPA1 dengan jumlah 25 siswa.

Tes yang digunakan adalah tes keterampilan menulis kalimat sederhana bahasa Jerman dengan judul Essen und Trinken yang disertai dengan potonganpotongan gambar yang sesuai dengan kata kunci. Angket yang diberikan ada 20 nomor dalam bentuk angket tertutup. Pemberian angket ini bertujuan untuk memperoleh data dan informasi yang berkaitan dengan keterampilan menulis kalimat sederhana bahasa Jerman.

Untuk menganalisis data digunakan teknik persentase. Dengan kata lain, data dari hasil penelitian dianalisis dengan menggunakan teknik persentase. Adapun rumus yang digunakan adalah sebagai berikut:

$$
\%=\frac{\text { Skor rata }- \text { rata }}{\text { skor maksimal }} \times 100
$$

Sudjana (2008: 67)

Sedangkan untuk mencari skor ratarata dihitung dengan menggunakan rumus : 
Keterampilan Menulis Kalimat Sederhana Bahasa Jerman dengan Menggunakan Media Gambar Siswa Kelas XI IPA Madrasah Aliyah Negeri 1 Makassar

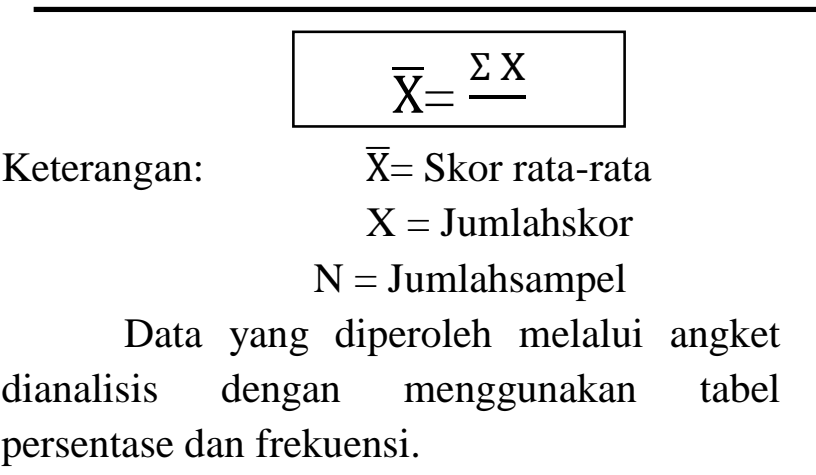

\section{HASIL DAN PEMBAHASAN}

Hasil analisis data tes keterampilan menulis Kalimat Sederhana bahasa Jerman dengan Menggunakan Media Gambar siswa Kelas XI IPA MAN (Madrasah Aliyah Negeri)1Makassar menunjukkan bahwa keterampilan menulis kalimat sederhana bahasa Jerman siswatermasuk dalam kategori cukup dengan perolehan nilai sebesar $\mathbf{6 0 , 9 \%}$. Hal ini disebabkan karena hanya sebagian siswa yang mengalami kesulitan-kesulitan dalam menulis kalimat sederhana Bahasa Jerman dengan menggunakan gambar terutama salah penulisan huruf misalnya pada penulisan kata kerja seperti möge, adapun siswa menuliskan dengan huruf kecil seperti familie, juga pada kata restaurant, kesalahan ini disebabkan karna sebagian siswa belum mengusai ortografi bahasa Jerman sehingga siswa mengalami kesalahan dalam menulis, serta cukup menguasai kosakata bahasa Jerman, pemilihan kata, pembentukan kata dan makna kata juga sangat berpengaruh pada tulisan misalnya pada pemilihan kata penghubung merupakan kata yang banyak digunakan oleh siswa, pemilihan kata yang tidak komunikatif sehingga sulit untuk dimengerti maknanya, siswa sedikit memiliki kesulitan dalam menguasai struktur kalimat. Jadi dalam menulis Bahasa Jerman sebagian siswa belum menguasai leksikalkata, morfologi, sintaksis serta ortografi kalimat bahasa Jerman.

Hasil analisis data angket keterampilan menulis siswa kelas XI IPA MAN (MDjiasahdono (2011: 21 Aliyah Negeri) 1 Makassar di bagi menjadi dua faktor yaitu:

\section{Faktor Penghambat}

Diketahui bahwa faktor eksternal yang paling memengaruhi keterampilan menulis kalimat sederhana bahasa Jerman dengan menggunakan media gambar adalah faktor intelegensi, sikap dan minat.Hal ini dapat dilihat dari hasil angket yang menunjukkan bahwa bahasa Jerman membuat banyak siswa tertarik mempelajarinya dan menganggappelajaran bahasa Jerman merupakan pelajaran yang sangat penting untuk dipelajari serta penggunaan media merupakan penunjang keterampilan menulis.

\section{Faktor Penunjang}

Berdasarkan hasil analisis angket di atas, disimpulkan bahwa faktor-faktor yang memengaruhi keterampilan menulis kalimat sederhana Bahasa Jerman siswa kelas XI IPA Madrasah Aliyah Negeri (MAN) 1 Makassar terdapat dua faktor yaitu faktor penunjang dan faktor penghambat yang berasal dari guru, dan siswa sendiri.

\section{KESIMPULAN}

Keterampilan menulis $\begin{array}{r}\text { Kalimat } \\ \text { Sederhana bahasa Jerman }\end{array}$
menggunakan media Gambar Siswa kelas XI
IPA1 Madrasah Aliyah Negeri (MAN) 1
Makassar termasuk dalam kategori Cukup
dengan persentase 60,93\%. Hasil penelitian
ini menunjukkan bahwa hasil tes
keterampilan menulis Kalimat sederhana


Keterampilan Menulis Kalimat Sederhana Bahasa Jerman dengan Menggunakan Media Gambar Siswa Kelas XI IPA Madrasah Aliyah Negeri 1 Makassar

bahasa Jerman dengan menggunakan media gambar siswa kelas XI IPA 1 adalah Cukup, karena didalam keterampilan menulis kalimat sederhana memiliki 2 faktor yaitu factor internal dan factor eksternal.

\section{REFERENSI}

Angkowono, $\mathrm{R}$ dan A. Kosasih. 2007.Optimalisasi Media Pembelajaran. Jakarta: PT. Grasindo.

Arsyad, Azhar. 2014. Media Pembelajaran. Jakarta: Rajawali Pers.

Jakarta: Rajawali Pers.

Aqib, Zainal. 2013. Model-Model, Media, dan Strategi Pembelajaran Konstektual (Inovatif). Bandung: Yrama Widya.

Caswell, R, and Mahler, B. 2004.Strategies of Teaching Writing. New York. ASCD Publication

Crème, ,P, and Lea, M.R. 2003. Writing at University.Maidenhead: Open University Press.

Chaer.2011. Kemampuan Menulis Karangan Sederhana Bahasa Jerman melalui media gambar kelas XI SMA Negeri 1 Borong Sinjai Skripsi: FBS

Dalman. 2012. Keterampilan Menulis. Jakarta: Rajawali Pers.

Djiwandono, Soenardi. 2011. Tes Bahasa. Jakarta: Indeks.

Hornby. A. S. 2000. Oxford AdvamceLearneds Oxford University Press.

Iskandar wasid dan Dadang Sunendar. 2008. Strategi Pembelajaran Bahasa. Bandung: PT. Rosdakarya.

Jauhari, Heri. 2013. Terampil Mengarang. Bandung: Quadra.
Jufri.

2001.

Prinsip-

PrinsipStrategiPembelajaranBahasa.

Makassar: State University of Makassar Press.

Junus, H. A Muhammad, Junus. A. Fatimah. 2011. KeterampilanBerbahasaTulis. Makassar: UNM

Kast, Bernd. 1999. FertigkeitSchreiben. München: Goethe Institut.

Kuncoro, Mudrajad. 2009. Mahir Menulis: Kiat Jitu Menulis Artike lOpini, Kolomdan Resensi Buku. Jakarta: Erlangga. 